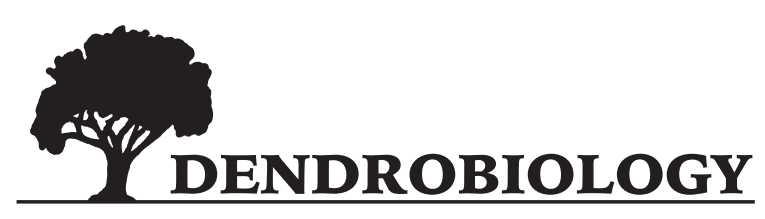

2019, vol. 81, 86-96

http://dx.doi.org/10.12657/denbio.081.010

\author{
Antoni Zięba, Wojciech Różański, Marcin Bukowski, \\ Barbara Ciesielska, Jerzy Szwagrzyk
}

\title{
Distribution and habitat conditions of Pinus cembra forests in the Tatra Mountains
}

\author{
Received: 10 April 2019; Accepted: 25 July 2019
}

\begin{abstract}
Relic Pinus cembra forests were among the least studied plant communities in the Western Carpathians. Their distribution in this mountain range is limited only to the Tatras. The lack of comprehensive research on the Polish and Slovakian sides of the Tatras led to considerable discrepancy regarding their distribution (300-1170 ha) as well as habitat conditions. Their occurrence on limestones and in the Western Tatras was contested. Therefore, the aim of this work was to determine the distribution and habitat conditions for the occurrence of Swiss stone pine forests in the Tatras. We mapped the entire range of the distribution of these forests, using the topographic method and digitized it in ArcGIS 10.2.2. Afterwards, we undertook spatial analysis, using DEM regarding their occurrence, depending on: altitude, inclination, solar radiation, exposure, geology and soil. To determine the preferable site conditions we used the logistic regression model. The total area of $P$. cembra forests in the Tatras is 916.93 ha. They occur in all mountain ranges within the Tatras. Altitude, inclination and solar radiation have significant impacts on the occurrence of these forests. The odds of the occurrence of $P$. cembra forests increased by $0.5 \%$ for every $1 \mathrm{~m}$ of altitude, by $2 \%$ for every $1^{\circ}$ of inclination and decrease by $0.1 \%$ for every $1 \mathrm{MJ} / \mathrm{m}^{2} /$ year of solar radiation. The majority of these forests grow in the altitude range $1300-1650 \mathrm{~m}$ a.s.1. (95\%) and on slopes with $20-60^{\circ}$ inclinations $(80 \%)$. Swiss stone pine forests occur both on slopes with low $\left(1900 \mathrm{MJ} / \mathrm{m}^{2}\right)$ and high annual solar radiation $\left(3400 \mathrm{MJ} / \mathrm{m}^{2}\right)$. They prefer slopes with North-western exposure. They may grow both on granite and limestone, while the majority of them were mapped on granite. Pinus cembra forests grow on diverse soils, both acidic and alkaline. Nevertheless, most of them occur on Haplic Podzols (52\%). The results may be applicable to the Tatra National Park for the conservation and monitoring of this Natura 2000 habitat.
\end{abstract}

Key words: subalpine forest, Natura 2000 habitat, GIS analysis, habitat modelling

Addresses: A. Zięba, Tatra National Park, ul. Kuźnice 1, 34-500 Zakopane, Poland; Department of Forest Biodiversity, Institute of Forest Ecology and Silviculture, University of Agriculture in Kraków, al. 29 listopada 46, 31-425 Kraków, Poland, e-mail: azieba@tpn.pl

W. Różański, Department of Forest Biodiversity, Institute of Forest Ecology and Silviculture, University of Agriculture in Kraków, al. 29 listopada 46, 31-425 Kraków, Poland, e-mail: rlrozans@cyf-kr.edu.pl M. Bukowski, Tatra National Park, ul. Kuźnice 1, 34-500 Zakopane, Poland, e-mail: mbukowski@tpn.pl B. Ciesielska, Institute of Mathematics, Jagiellonian University, ul. prof. Stanisława Łojasiewicza 6, 30-348 Kraków, Poland, e-mail: barbara.ciesielska.uj@gmail.com

J. Szwagrzyk, Department of Forest Biodiversity, Institute of Forest Ecology and Silviculture, University of Agriculture in Kraków, al. 29 listopada 46, 31-425 Kraków, Poland, e-mail: rlszwagr@cyf-kr.edu.pl 


\section{Introduction}

Subalpine stands with Swiss stone pine (Pinus cembra L.), Norway spruce (Picea abies (L.) H.Karst) and European larch (Larix decidua Mill.) occur along the timberline, in the Alps and in the Carpathians (Myczkowski \& Bednarz, 1974; Jamnický, 1981; Ozenda, 1983; Dražil, 2002; Casalegno et al., 2010; Caudullo \& de Rigo, 2016). Most of these stands are situated on steep and rocky slopes, where Swiss stone pine and larch are not subject to competition from the shade-tolerant Norway spruce. Furthermore, most of the researchers link their distribution, both in the Alps and in the Carpathians with a more continental climate (Myczkowski et al., 1971; Ellenberg, 1978; Casalegno et al., 2010; Caudullo \& de Rigo, 2016). However, it is worth emphasizing that both in the Alps and in the Carpathians the primal range of the $P$. cembra forests have shrunk due to long-lasting human activities (Jamnický, 1963, 1964; Paryski, 1971; Ellenberg, 1978; Casalegno et al., 2010).

Swiss stone pine forests are among the least studied plant communities in the Tatra Mountains. Research concerning stone pine forests was carried out in the 1960/1970's by Stefan Myczkowski. It was primarily focused on the floristic description of such forests, whereas issues related to the habitat conditions of $P$. cembra forests were mostly based on the observations and literature data from the Alps. Likewise, the distribution of $P$. cembra forests in the Tatras was based on fragmentary mapping (Myczkowski, 1971; Browicz \& Gostyńska-Jakuszewska, 1974). Further surveys regarding the distribution of Swiss stone pine forests were carried out by Jamnický (1981) in the Slovakian Tatras and by Chmiel (1996) on the Polish side. More precise data concerning the distribution and site conditions were collected only in the selected Tatra valleys, such as Gąsienicowa Valley (Zwijacz-Kozica et al., 2010).

Several syntaxonomical studies regarding the $P$. cembra forests were carried out in the Tatras until the beginning of the $21^{\text {st }}$ century (Myczkowski \& Lesiński, 1974; Wojterska et al., 2004; Kanka, 2008). However, insufficient data, as well as a lack of comprehensive research on the Polish and Slovakian sides of the Tatras led to contesting the status of Swiss stone pine forests as a separate plant association (Matuszkiewicz, 2008). The syntaxonomic status of these forests has been settled recently (Zięba et al., 2018). P. cembra forests of the Tatra Mountains form a separate plant community, different from the upper montane spruce forests. They are divided into Vaccinio-Pinetum cembrae Oberd. 1962 - relic Swiss stone pine forest (similar to those from the silicate Alps) and Swertio perennis-Pinetum cembrae Zięba, Różański, Szwagrzyk 2018 - calcicolous relic Swiss stone pine forest (Zięba et al., 2018).
Knowledge related to the distribution and habitat requirements of $P$. cembra forests has been also very limited. Most of the authors were focused on the horizontal and vertical distribution of the species, but not on the area and distribution of $P$. cembra forests. They pointed out the lack of localities of $P$. cembra in the North-western parts of the Tatras and minimal (945 m a.s.l. - Vtáčie turne) as well as maximal (1821 m a.s.l. - Mlynica) altitudes of the localities (Pawłowski, 1956; Jasičová, 1966; Browicz \& Gostyńska-Jakuszewska, 1974). Later studies lifted the uppermost sites of single, dwarfish individuals to 2079 m a.s.l. on Żabia Czuba (Skrzydłowski et al., 2011). The first work regarding the distribution of $P$. cembra forests occurred only in the second half of the 20 $0^{\text {th }}$ century (Myczkowski et al., 1971; Jamnický, 1981). The estimated area of these forests varied depending on the authors, from ca. 300 to 1170 ha in the entire Tatras (Jamnický, 1981; Fleischer \& Chmiel, 2010), and from ca. 30 to 130 ha on the Polish side (Myczkowski et al., 1971; Mirek et al., 2013). Moreover, according to the Polish literature, Swiss stone pine forests were limited to the High Tatras and granite bedrock (Myczkowski \& Lesiński, 1974; Matuszkiewicz, 2008).

Therefore, the aims of this work were to 1) determine the distribution of Swiss stone pine forests based on the mapping of the entire Tatras; 2) verify the distribution of $P$. cembra forests in the Western Tatras and on limestone and dolomite bedrock; and 3) determine the habitat conditions of the occurrence of $P$. cembra forests based on the previously mapped distribution and digital elevation model (DEM), as well as geological, soil and solar radiation maps (Piotrowska et al., 2015; Skiba et al., 2015; Wojkowski, 2015).

\section{Material and Methods}

\section{Study area}

The research was carried out in the Tatra Mountains, which are the only area in the Western Carpathians where Swiss stone pine occurs naturally. The Tatras are the highest mountains in the entire Carpathians (highest peak: Gerlachovský štít/Gerlach $2655 \mathrm{~m}$ a.s.1.), and are divided between Poland and Slovakia. The total area of the Tatra Mountains is ca. 79000 ha. Based on the geomorphology, flora and elevation they are divided into three parts: Western Tatras (41 856 ha), High Tatras (31 534 ha) and Belianske Tatras (5 613 ha) (Balon et al., 2015). They are an island in the alpine-type landscape in the Western Carpathians with well-developed mountain vegetation belts (up to the sub-nival zone) (Mirek, 1996; Balon et al., 2015). High altitude, geographic 


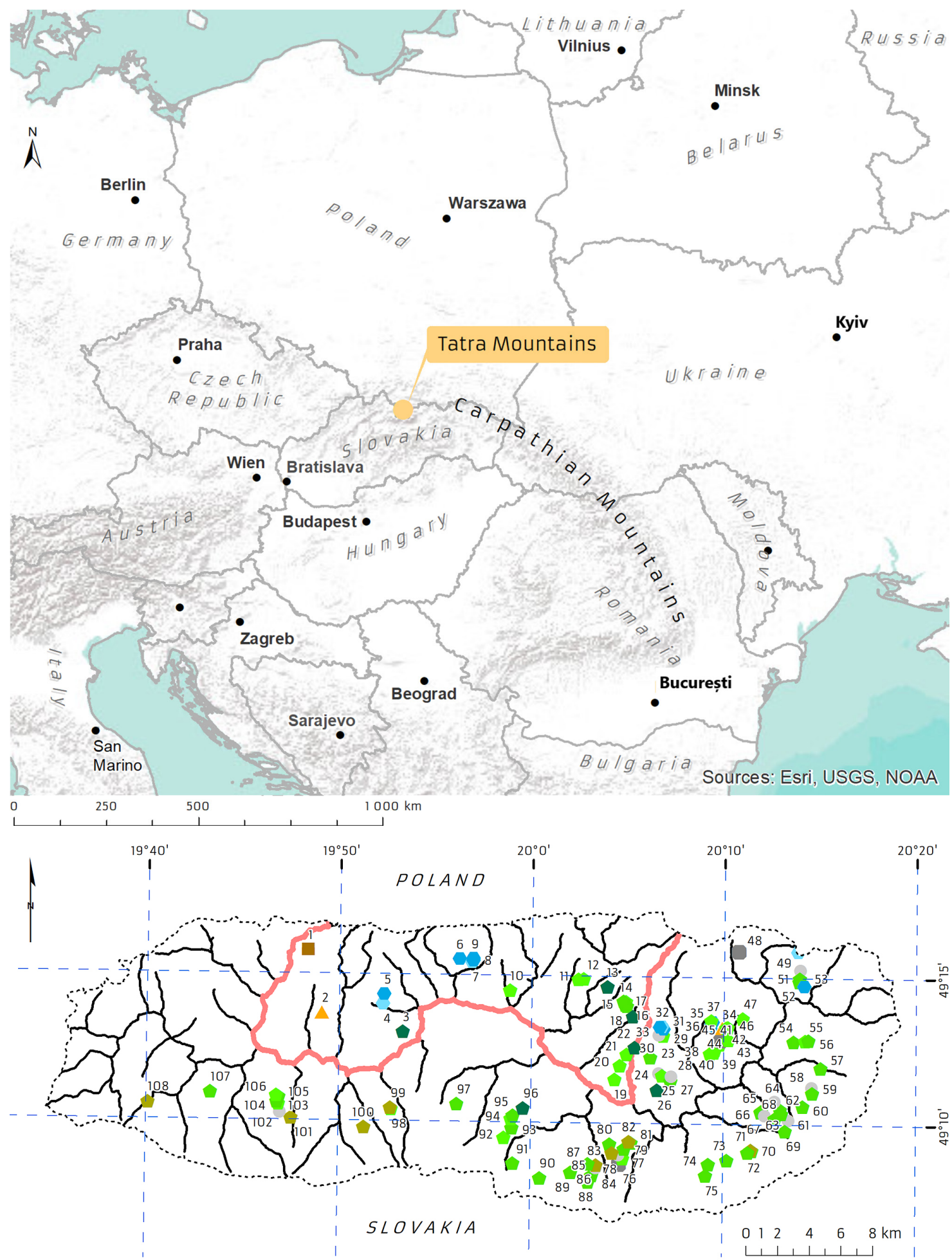

\section{PINUS CEMBRA FORESTS OF THE TATRA MOUNTAINS}

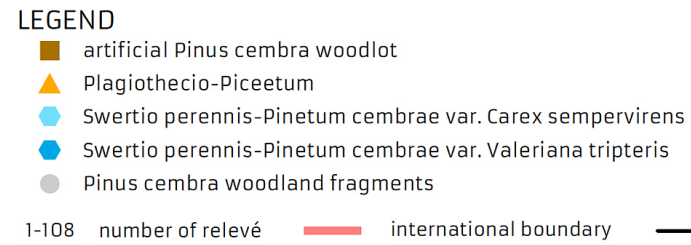
Pinus cembra woodland fragments/Plagiothecio-Piceetum
Vaccinio-Pinetum cembrae typicum var. Cladonia spp.
- Vaccinio-Pinetum cembrae typicum var. Larix decidua
Vaccinio-Pinetum cembrae typicum var. Gymnocarpium dryopteris Vaccinio-Pinetum cembrae juncetosum trifidi

Fig. 1. Study area, with the location of phytosociological relevés used in the mapping for determination of Pinus cembra forests (depiction of phytosociological units according to Zięba et al., 2018) 
isolation and diverse bedrock caused the survival of unique fauna and flora. They are a biodiversity hotspot with ca. 1300 species of vascular plants, 700 species of bryophytes and 850 species of lichens (Ochyra, 1996; Szweykowski, 1996; Tobolewski, 1996; Mirek \& Piękoś-Mirkowa, 2003; Górski \& Váňa, 2014; Mráz \& Ronikier, 2016).

\section{Data collection}

The field work was carried out in the entire vertical and horizontal range of distribution of $P$. cembra in the Tatras. The mapping was made based on the topographic method (Faliński, 1990). As base maps, either topographic maps or orthophotos were used, with a scale not smaller than 1:20 000. The classification of certain areas into Swiss stone pine forests was based on the following criteria: 1) the occurrence of $P$. cembra in forest communities (single trees above the timberline, e.g., in Pinus mugo Turra shrubs, were not included); 2) the share of P. cembra in the stand was at least $20 \%$ - based on the data from 108 sampling plots (phytosociological relevés - the area of single relevé: $250 \mathrm{~m}^{2}$ ) located in the entire range of research and field observations of the stand; and 3) the syntaxonomic identity. We took into account patches belonging to one of two plant associations: Vaccinio-Pinetum cembrae or Swertio perennis-Pinetum cembrae, based on the data from 108 relevés located in the entire range of research (Zięba et al., 2018) (Fig. 1).

Next, the data collected from the field were digitized in ArcGIS 10.2.2. As a result we received the base of the geometrical objects, with specific area and in which the apexes had certain geographical coordinates. Afterwards we undertook analyses based on the geographical location of the objects representing the Swiss stone pine forests and the physiography of the areas on which those forests grew. Analyses related to the topographical relief were made based on the photogrammetric digital elevation model (DEM), with the terrain pixel resolution of $10 \mathrm{~m}$. The altitude layer [m a.s.l.] was generated in the Spatial Analyst tools (ESRI, 2009). Next, based on the DEM in the ArcGIS 3D Analyst we generated layers for exposure $\left[^{\circ}\right]$ and inclination $\left[^{\circ}\right]$. Beside the topographic features we used other site variables, such as geology (bedrock), soil and solar radiation, developed for the entire Tatras for the Atlas of the Tatra Mountains (Dąbrowska \& Guzik, 2015). As a result of the spatial imposition of all those data, we obtained the informational layer describing the area encompassed by the Swiss stone pine forests. These data were transformed into MS Excel format and used for the spatial description of the habitat conditions of the Swiss stone pine forests. In addition to that, for the entire Tatras we generated a $50 \mathrm{~m} \times 50 \mathrm{~m}$ grid of sampling plots from which we collected similar data regarding the site conditions (ESRI, 2009). The data were afterwards transformed into a MS Excel format and used in logistic regression modelling.

The names of the topographic objects, bedrock and soil types followed the nomenclature used in the Atlas of the Tatra Mountains (Dąbrowska \& Guzik, 2015).

\section{Data analysis}

To investigate the habitat conditions determining the distribution of $P$. cembra forests in the Tatras we used the logistic regression model. This method enables a description of the dependence between the variables. It is used when the response variable $y$ has only two outcomes ( 0 or 1 ), such as in our case, the occurrence of Swiss stone pine forests (1) or lack of these forests (0) (Cox, 1958; Pohar et al., 2004; Rencher \& Schaalje, 2008).

We made three models:

1. for the entire Tatras - from the foothills, to the summits of the highest peaks, including data from all of the sampling plots from the $50 \mathrm{~m} \times 50 \mathrm{~m}$ grid;

2. up to $1550 \mathrm{~m}$ a.s.1. - this model includes data from the sampling plots, from the foothills up to the theoretical timber line in the Tatra Mountains (Sokołowski, 1928; Piękoś-Mirkowa \& Mirek, 1996);

3. up to $1700 \mathrm{~m}$ a.s.l. - this model includes data from the sampling plots, from the foothills up to the highest records of timber line in the Tatra Mountains (Sokołowski, 1928; Zięba et al., 2018).

For the nominal variables we used the following baselines: soils - Haplic Podzols (Skeletic), geology - granite. These are preferred by P. cembra types of soils and bedrock in the Tatras according to the literature (Myczkowski, 1971; Myczkowski \& Lesiński, 1974; Zarzycki et al., 2002; Matuszkiewicz, 2008). In the case of exposure, the odds of this variable were presented by the odds ratio (Cox, 1958; Szumilas, 2010).

All models were fitted with statistical software, $R$ version 3.5.1 using the glm function from the stats package with a binomial distribution of the response variable (R Development Core Team, 2018).

\section{Results}

The total area of the Swiss stone pine forests in the Tatras is about 917 ha. The majority of these forests grow in the Slovakian part of the Tatras -750.55 ha $(82 \%)$, and only 166.38 ha $(18 \%)$ are located in the Polish Tatras. The lowest patches occur at the elevation of $1179 \mathrm{~m}$ in the Roztoka Valley, whereas 
the highest reach is up to $1821 \mathrm{~m}$ in Mengusovská Valley. The furthermost North-west patches are located in the Kościeliska Valley, whereas the Southwest reach was the Jalovecká Valley. No Swiss stone pine forests were found in the furthermost West (massif of Sivý vrch) and North-west (Roháčska Valley, Osobitá massif, Chochołowska Valley) parts of the Tatras (Electronic Appendix). The share of the $P$. cembra forests in the respective mountain ranges and main valleys of the Tatras is presented in the Supplements 1 and 2. Even though the largest area of Swiss stone pine forests occurs in the High Tatras, the present data confirm the occurrence of these forests also in the Western Tatras and on limestone and dolomite bedrock. Pinus cembra forms a separate plan community on calcareous bedrock, called Swertio perennis-Pinetum cembrae (Zięba et al., 2018). The area of this association reaches 78.14 ha (only ca. 14.65 ha on Polish side). The remaining 838.79 ha represents the association Vaccinio-Pinetum cembrae.

The first model (entire Tatras) encompassed large areas that are naturally without forests, such as alpine tundra, and bare rocks in the sub-nival zone. Therefore we decided to reject it. We rejected also the second model (up to $1550 \mathrm{~m}$ a.sl.), because it did not include $27 \%$ of the sampling plots located in the $P$. cembra forests, which had an impact on the results of the modelling. Due to the fact that a significant part of the Swiss stone pine forests occur at the elevation 1500-1700 m a.s.l., we decided to make use of the third model. That model encompassed the majority of the woodlands and almost the entire range of P. cembra forests $(99.7 \%$ of sampling plots with these forests). The results of the logistic regression model are presented below (Table 1).

The altitude, slope inclination and solar radiation had significant impacts $(\mathrm{p}<0.001)$ on the occurrence of $P$. cembra forests in the Tatras. The odds of the occurrence of these forests increased by $0.5 \%$ for every $1 \mathrm{~m}$ of altitude (50\% for $100 \mathrm{~m}$ ) (Table 1$)$. The mean altitude of the occurrence of Swiss stone pine forests is $1455 \mathrm{~m}$ a.s.l. (standard deviation: $\pm 154 \mathrm{~m}$ ). 95\% (871.69 ha) of these forests grow 1300-1650 m a.s.l. (Fig. 2).

In the case of inclination, the odds of occurrence of Swiss stone pine forests increased $2 \%$ for every $1^{\circ}$ (Table 1). Pinus cembra forests occur mostly on steep

Table 1. Impact of the altitude, slope inclination and solar radiation on the occurrence of Swiss stone pine forests in the Tatra Mountains

\begin{tabular}{lccc}
\hline & $\begin{array}{c}\text { Altitude } \\
{[\mathrm{m} \text { a.s.1. }]}\end{array}$ & Inclination $\left[^{\circ}\right]$ & $\begin{array}{c}\text { Solar radiation } \\
{\left[\mathrm{MJ} / \mathrm{m}^{2} / \text { year }\right]}\end{array}$ \\
\hline Significance & 0.001 & 0.001 & 0.001 \\
p-value & $<2 \mathrm{e}-16$ & $<2 \mathrm{e}-16$ & $<2 \mathrm{e}-16$ \\
Odds & 1.004810 & 1.021520 & 0.9987784 \\
\hline
\end{tabular}

slopes, with a mean inclination of $27^{\circ}$ (standard deviation $\pm 11^{\circ}$ ) (Fig. 3).

The influence of solar radiation was relatively low. The odds of the occurrence of Swiss stone pine forests decreased by $0.1 \%$ for every $1 \mathrm{MJ} / \mathrm{m}^{2} /$ year (Table 1). $92 \%$ ( $840.39 \mathrm{ha}$ ) of these forests occurred on slopes with solar radiation between 1500 and 3700 $\mathrm{MJ} / \mathrm{m}^{2} /$ year (mean: $2786 \mathrm{MJ} / \mathrm{m}^{2} /$ year, standard deviation: $584 \mathrm{MJ} / \mathrm{m}^{2}$ ); however, we found two peaks, at $1900-2000 \mathrm{MJ} / \mathrm{m}^{2} /$ year and $3300-3400 \mathrm{MJ} / \mathrm{m}^{2} /$ year (Fig. 4).

Pinus cembra forests preferred slopes with a Western exposure. Altogether on slopes NW, W, SW occur 451.90 ha of these forests, which is almost $50 \%$ of

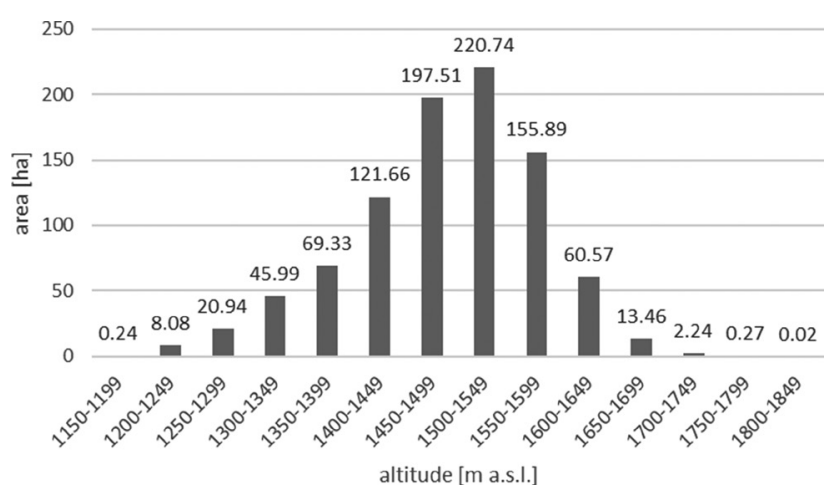

Fig. 2. Distribution of altitude of the patches of Swiss stone pine forests in the Tatra Mountain

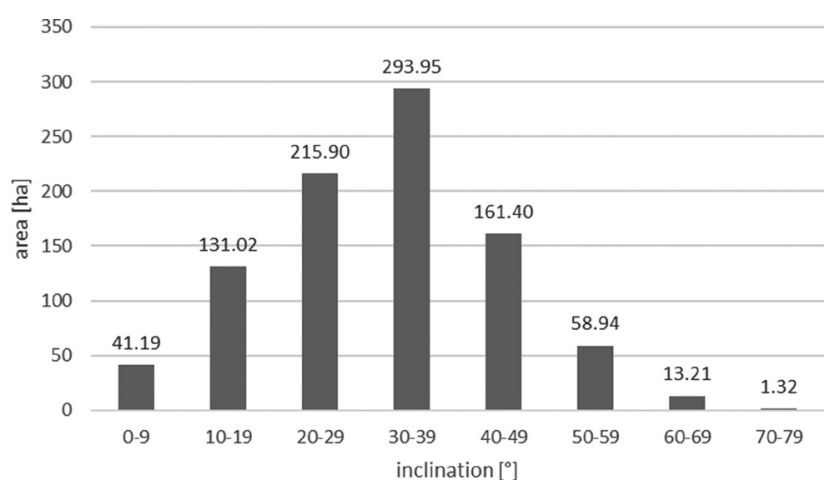

Fig. 3. Distribution of inclination of the patches of Swiss stone pine forests in the Tatra Mountains

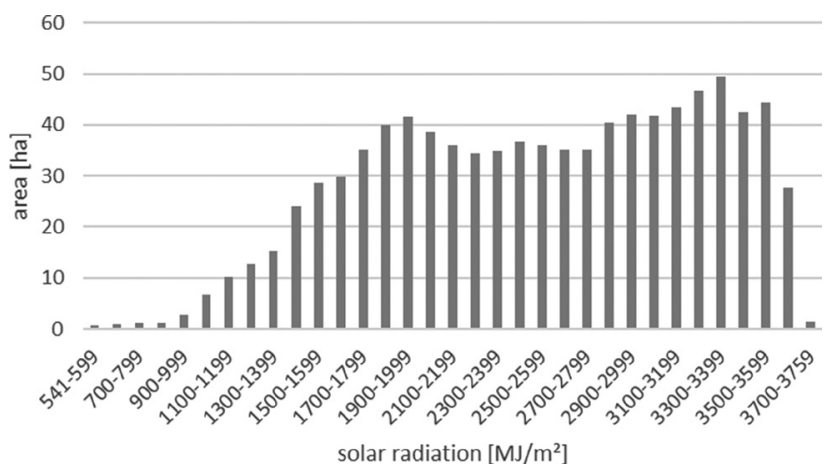

Fig. 4. Distribution of solar radiation on the patches of Swiss stone pine forests in the Tatra Mountains 


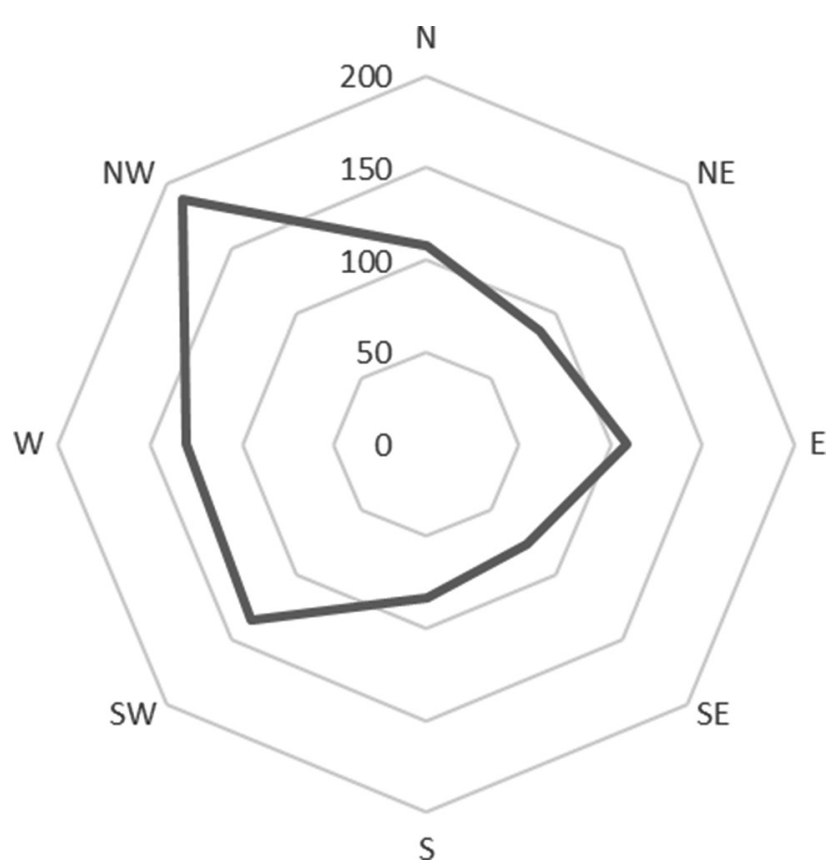

Fig. 5 Distribution of exposure of the patches of Swiss stone pine forests in the Tatra Mountains (area in [ha])

their total area in the Tatras (Fig. 5). The preferred slopes are those with a NW exposure. The odds of occurrence of Swiss stone pine forests on these slopes are higher than on any other and vary from $27 \%$ higher than on SW to $144 \%$ higher than on SE (Table 2).

Significant impacts $(\mathrm{p}<0.001)$ on the occurrence of $P$. cembra forests were found for the following types of bedrock: diorites, dolomites, gneisses, deluvial-fluvial sediments, glacigenous sediments, deluvial-eluvial sediments, limestones and conglomerates. We observed a lack of influence from the other types of bedrock. The odds of the occurrence of Swiss stone pine forests in almost all cases were less than on granites and amounted to $82 \%$ less than on granites for dolomites, $83 \%$ - gneisses, $25 \%$ - deluvial-fluvial sediments, $13 \%$ - glacigenous sediments, $59 \%$ - limestones and $84 \%$ - conglomerates. The odds for the remaining types of bedrock were exiguous, less than $99 \%$ in comparison to the baseline type (Supplement 3). The results of the modelling are coherent with the share of bedrock types in the Swiss stone pine forests (Fig. 6).

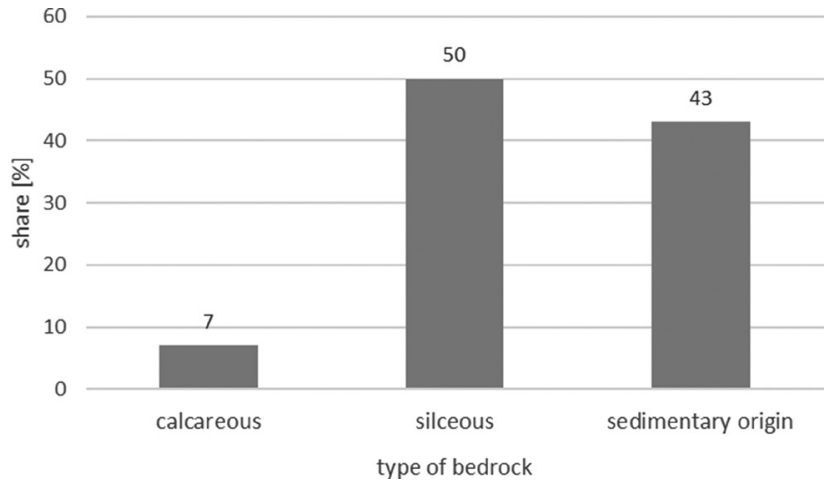

Fig. 6. The share of different bedrock types in the relic Swiss stone pine forests in the Tatra Mountains (calcareous: limestones, dolomites, conglomerates; siliceous: granites, gneisses; sedimentary origin: deluvial-fluvial sediments, glacigenous sediments, glacifluvial sediments)

There are significant influences $(\mathrm{p}<0.001)$ on the occurrence of $P$. cembra forests from 10 types of soil (Supplement 4). The odds of the occurrence of Swiss stone pine forests in all cases were less than on Haplic Podzols (Skeletic) and amounted to $48 \%$ less than on Haplic Podzols (Skeletic) for Lithic Leptosols, 55\% - Entic Podzols and Leptic Podzols, 36\% - Folic Leptosols, 72\% - Regosols (Hyperskeletic),

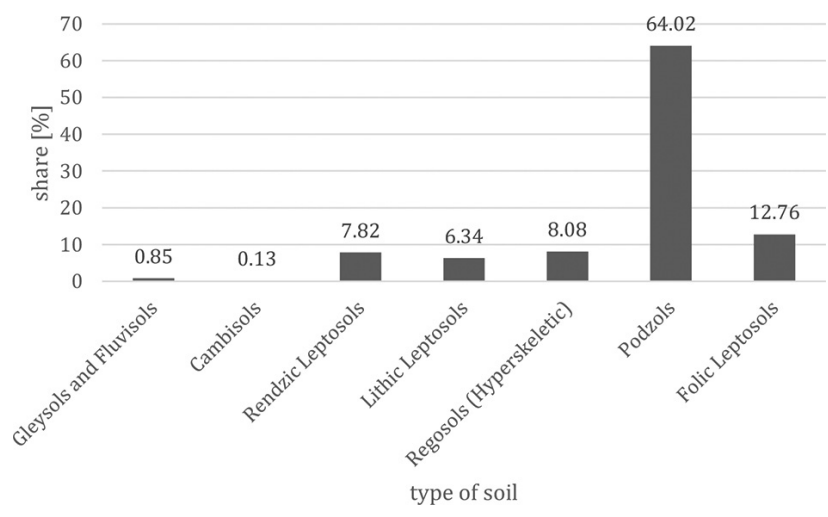

Fig. 7. The share of soil types in the relic Swiss stone pine forests in the Tatra Mountains (Cambisols: Haplic Cambisols (Dystric, Skeletic), Haplic Cambisols (Eutric); Rendzic Leptosols: Rendzic Leptosols, Folic Rendzic Leptosols, Rendzic Leptosols (Skeletic), Cambic Rendzic Leptosols; Podzols: Entic Podzols, Leptic Podzols, Haplic Podzols (Skeletic))

Table 2. The odds ratio of occurrence of Swiss stone pine forests in the Tatra Mountains for different exposures

\begin{tabular}{ccccccccc}
\hline & $\mathrm{N}$ & $\mathrm{NE}$ & $\mathrm{E}$ & $\mathrm{SE}$ & $\mathrm{S}$ & $\mathrm{SW}$ & $\mathrm{W}$ & $\mathrm{NW}$ \\
\hline $\mathrm{N}$ & 1 & 0.91070 & 1.04242 & 0.75724 & 0.93711 & 1.45345 & 1.32402 & 1.84807 \\
$\mathrm{NE}$ & 1.09806 & 1 & 1.14463 & 0.83149 & 1.02900 & 1.59597 & 1.45385 & 2.02929 \\
$\mathrm{E}$ & 0.95931 & 0.87364 & 1 & 0.72643 & 0.89898 & 1.39431 & 1.27014 & 1.77287 \\
$\mathrm{SE}$ & 1.32059 & 1.20266 & 1.37660 & 1 & 1.23754 & 1.91941 & 1.74848 & 2.44054 \\
$\mathrm{~S}$ & 1.06711 & 0.97181 & 1.11237 & 0.80805 & 1 & 1.55098 & 1.41286 & 1.97209 \\
$\mathrm{SW}$ & 0.68802 & 0.62658 & 0.71720 & 0.52099 & 0.64475 & 1 & 0.91095 & 1.27151 \\
$\mathrm{~W}$ & 0.75528 & 0.68783 & 0.78731 & 0.57193 & 0.70778 & 1.09776 & 1 & 1.39581 \\
$\mathrm{NW}$ & 0.54110 & 0.49278 & 0.56406 & 0.40975 & 0.50708 & 0.78647 & 0.71643 & 1 \\
\hline
\end{tabular}


$66 \%$ - Cambic Rendzic Leptosols, 86\% - Folic Rendzic Leptosols, $67 \%$ - Rendzic Leptosols (Skeletic) and $76 \%$ - Rendzic Leptosols. The odds for the remaining soils were exiguous, and less than $99 \%$ in comparison to the baseline soil (Supplement 4). The results of the modelling are coherent with the share of soil types in the Swiss stone pine forests (Fig. 7).

\section{Discussion}

The area of the Swiss stone pine forests in the entire Tatras (916.93 ha) represents just ca. $1.6 \%$ of the woodlands in these mountains. This value differs considerably from the area measured by Jamnický (1981) (249.64 ha). Even though, recent data presented by Fleischer and Chmiel (2010) show a larger area of $P$. cembra forests (1170 ha), they vary by ca. 250 ha in comparison to our results. These differences could be a result of the terrain difficulties that might affect the accuracy of the earlier mapping. The differences may also be caused by different classifications of the patches of vegetation to certain plant communities, e.g., including single $P$. cembra trees or small groups of trees above the timberline to forest communities. Furthermore, it is worth adding that both Polish and Slovakian National Parks planted these trees in the second half of the $20^{\text {th }}$ century (Jamnický, 1981). Some of these patches, which were relatively young at the time of Jamnický's research, could nowadays be classified as Swiss stone pine forests.

The largest area of Swiss stone pine forests occurs in the High Tatras. Vast complexes of these forests survive in the least accessible parts of the Białka and Kôprová valleys. Even though the smallest patches of $P$. cembra forests grow in the Belianske Tatras, it is worth emphasizing that this is the smallest part of the Tatras. In this context, the relatively small area of $P$. cembra forests in the Western Tatras is striking. Forests on more accessible slopes of the Western Tatras were more exploited over centuries by loggers, miners and shepherds. The price of Swiss stone pine wood exceeded the values of any other tree species by $300 \%$ (Jamnický, 1964), which resulted in a significant destruction of $P$. cembra forests (Bukovčan, 1969). Unlike in the High Tatras, less accessible terrain, together with a different ownership structure favoured the survival of threatened Swiss stone pine and larch forests (Madeyski, 1974). However, wherever on the Western Tatras slopes which were steep enough to stop the forest exploitation, $P$. cembra forests survived. Such a relatively large and pristine fragment has survived at the massif of the Otrhance and was known already in the $18^{\text {th }}$ century (Bel, 1736).

Our study confirms, that the Swiss stone pine forests occur in the Tatras mostly at the elevation
1300-1650 m a.s.l. (Pawłowski, 1956; Browicz \& Gostyńska-Jakuszewska, 1974; Myczkowski \& Lesiński, 1974; Piękoś-Mirkowa \& Mirek, 1996). However, the lowest patches may grow even at ca. $1180 \mathrm{~m}$ a.s.l. (Roztoka Valley) in the lower montane belt. Almost $50 \%$ of these forests grow at the transition zone (1500-1650 m a.s.l.) between the upper montane belt and subalpine dwarf pine (Pinus mugo) shrubs, which corresponds to the results of the research by Zwijacz-Kozica et al. (2010). 25\% of P. cembra forests are located above the theoretical timberline (1550 $\mathrm{m}$ a.s.1.) in the Tatras (Sokołowski, 1928; Piękoś-Mirkowa \& Mirek, 1996; Valachovič, 2014). The highest patches grow at an elevation of ca. 1820 $\mathrm{m}$ a.s.l. in the Mengusovská Valley.

The occurrence of Swiss stone pine forests at such an elevation is related to the adaptation of this tree to a severe mountain climate (Tranquillini, 1979; Holtmeier, 2003; Erschbamer \& Wallnofer, 2007). The mean annual temperature in the habitats of $P$. cembra in the Alps reaches barely $+1.5^{\circ} \mathrm{C}$. The minimum growing season for the survival of Swiss stone pine forests should be 60-70 days, with an optimum of 90 days with an average mean temperature greater than $10^{\circ} \mathrm{C}$ (Ellenberg, 1978; Casalegno et al., 2010; Leuschner \& Ellenberg, 2017). In the Tatras, P. cembra forests grow in the zone of cool climate with the mean annual temperature of $+3^{\circ} \mathrm{C}$ and snow cover lasting for ca. 150 days/year (Ustrnul et al., 2015; Żmudzka et al., 2015; Zięba et al., 2018). Even though the climatic conditions at such altitudes are not favourable for either P. cembra or Larix decidua, these two species gained an ecological advantage over the competitive Picea abies, and therefore form their own separate forest belt (Ellenberg, 1978; Caudullo \& de Rigo, 2016; Leuschner \& Ellenberg, 2017).

Similar to harsh climatic conditions, steep slopes foster the occurrence of Swiss stone pine forests. At slopes with an inclination above $35^{\circ}$, the competitive capabilities of Norway spruce decrease. This ensures larger gaps in the stand and provides better growth conditions for species that demand more light, such as P. cembra (Holeksa \& Szwagrzyk, 2004). Furthermore on the steep cliffs and ridges, snow is constantly blown up, which supports its faster melting. Therefore, these areas are often visited by spotted nutcrackers (Nucifraga caryocatactes L.), the main disperser of $P$. cembra seeds, which supports its natural regeneration. Rocky ridges are not affected by avalanches, which make them safe sites for forest communities (Myczkowski \& Bednarz, 1974). It is worth emphasizing that steep slopes not only support $P$. cembra in its competition with Picea abies, but also protect these forests from direct human impact. Therefore, some patches of these relic woodlands in the Tatras retained a pristine character (Bednarz, 1969; Zielonka, 2010; Zięba et al., 2018). 
P. cembra is considered to be one of the most light demanding tree species (Myczkowski \& Bednarz, 1974; Zarzycki et al., 2002). Its abundant occurrence in the inner Alps is in contrast to the Prealps, which was explained by the continentality of the climate and especially higher insolation in the summer season (Ellenberg, 1978; Leuschner \& Ellenberg, 2017). A similar dependence on the continental microclimate was described from the Tatras (Myczkowski \& Bednarz, 1974).

Nevertheless, the results of our study do not confirm a strong dependence for the occurrence of Swiss stone pine forests on the high solar radiation and continental climate. In fact, $32 \%$ of these forests grow on areas with higher solar radiation $(>3000$ $\mathrm{MJ} / \mathrm{m}^{2} /$ year, max. $3759 \mathrm{MJ} / \mathrm{m}^{2} /$ year). However, this seems to be still much lower than the maximum for the Tatras (4600 MJ/m²/year) and similar to the mean annual value for the town of Zakopane (3623 $\mathrm{MJ} / \mathrm{m}^{2}$ /year) (Wojkowski, 2015). A considerable part of the Swiss stone pine forests in the Tatras grow on the shady and humid North and North-western slopes with rather low solar radiation (ca. $1900 \mathrm{MJ} /$ $\mathrm{m}^{2}$ /year). In this context, it is worth recalling some older publications. Sokołowski (1928) and Somora (1958) evaluated that $P$. cembra forests prefer cooler and more humid slopes with an oceanic climate. Likewise, in the Southern Carpathians, Swiss stone pine is more dominant in the areas with oceanic influences (Blada, 2008).

In addition to that, various authors compared the continental conditions for the occurrence of Swiss stone pine forests in Central European mountains to those in the Siberian taiga with Pinus sibirica Du Tour (Myczkowski, 1969; Myczkowski \& Lesiński, 1974; Ellenberg, 1978; Leuschner \& Ellenberg, 2017). However, the dark taiga with $P$. sibirica, Abies sibirica Ledeb. and Picea obovata Ledeb. is classified in this area as humid forests, in contrast to the continental light Larix sibirica Ledeb. or Larix gmelinii (Rupr.) Kuzen. taiga (Nazimova \& Polikarpov, 1996). Furthermore, there is information from the Alps that Swiss stone pine - European larch forests may grow in very diverse areas in terms of precipitation (700$2000 \mathrm{~mm}$ /year). Even though they may grow in regions with very high precipitation, their distribution is limited to areas with relatively dry summers. Therefore, the belt of Swiss stone pine forests did not emerge in the Prealps (Ellenberg, 1978; Leuschner \& Ellenberg, 2017).

The Swiss stone pine forests occur in the Tatras mostly on slopes with Western exposure (NWSW-W), which are more affected by the cool and humid impact of the Atlantic climate. Similar results regarding the preference for a North-western exposure were detected in the Sucha Woda Valley (Zwijacz-Kozica et al., 2010). However, Zwijacz-Kozica et al. (2010) showed an almost complete lack of P. cembra on slopes with Southern or Eastern exposures. Such a result is probably linked to a limited area of research - a single valley on the Northern side of Tatras, with a relatively significant impact of shepherding on the current distribution of trees (Paryski, 1971; Zwijacz-Kozica et al., 2010). In the Alps, Swiss stone pine forests occur mostly on Northern exposures (Casalegno et al., 2010). A similar dependence on slope exposure was described from the Eastern Carpathians (Środoń, 1936).

This conviction regarding the preference or occurrence only on granite bedrock of $P$. cembra forests in the Tatras lasted for a long time, especially among Polish authors (Myczkowski \& Lesiński, 1974; Matuszkiewicz, 2008). On the other hand, Slovak geobotanists consequently pointed out its growth on both silicate and calcareous ground (Somora, 1959; Kanka, 2008). Recent floristic studies have revealed different plant associations with Swiss stone pine forests on granite and limestone bedrock on both sides of the Tatras (Kučera, 2017, 2018; Zięba et al., 2018).

A similar ostensible connection of $P$. cembra forests to granite bedrock was also described in the past from the Alps, which was mentioned by Ellenberg (1978) and Leuschner and Ellenberg (2017). However, more recent publications underline their distribution on both silicate and calcareous ground (Willner \& Grabherr, 2007; Casalegno et al., 2010; Caudullo \& de Rigo, 2016; Leuschner \& Ellenberg, 2017).

The majority of Swiss stone pine forests grow on poor and acidic Haplic Podzols, which confirms the former observations (Myczkowski, 1971; Fleischer \& Chmiel, 2010). Nonetheless, relic P. cembra forests also occur on more fertile and alkaline soils, such as Rendzic Leptosols. Such habitats for Swiss stone pines are particularly found in the Belianske Tatras (Somora, 1959). Soils developed from limestones and dolomites harbour the relic calcicolous Swiss stone pine forests Swertio perennis-Pinetum cembrae (Zięba et al., 2018). A similar plant association, called Rhododendro hirsuti-Pinetum cembrae Bojko 1931 was described from the Alps (Willner \& Grabherr, 2007).

The results of this research are applicable for the park management, including the Natura 2000 habitat monitoring and reporting. In the case of the Polish Tatra National Park, the presented area of Swiss stone pine forests (habitat: 9420 - Alpine Larix decid$u a$ and/or $P$. cembra forests) has already been reported to the European Commission in the Standard Data Form (European Environment Agency, 2017), as well as being included in the current Project of the Management Plan of the Tatra National Park. It is worth adding, that the monitoring of these forests seem to be essential, since Casalegno et al. (2010) predict a 
rapid decrease of the suitable habitats for them in the Tatras after 2050, and even a risk of their complete loss after 2080, due to climate change. Fortunately, recent genetic research, insect-pest control, as well as studies regarding the structure of Swiss stone pine forests and their regeneration show their good condition (Zwijacz-Kozica \& Żywiec, 2007; Dzialuk et al., 2014; Grodzki et al., - accepted 2019). Therefore, no conservation tasks regarding these forests are currently needed in both National Parks. Their transboundary strict protection seems to be the best solution. However, the data provided in this research could potentially be used by park authorities for the active conservation of this species in the case of serious threat to it from climate change or if the National Parks decide to restore their lost areas.

\section{Acknowledgements}

The authors would like to thank the directorate of the Polish and Slovakian Tatra National Parks for the approval to perform this research.

\section{References}

Balon J, Jodłowski M \& Krąż P (2015) The Carpathians - physico-geographical regions: Atlas of the Tatra Mountains - Abiotic nature (ed. by K Dąbrowska \& M Guzik) Tatrzański Park Narodowy, Zakopane, Poland.

Bednarz Z (1969) Reliktowy las limbowo-świerkowy z modrzewiem pod Czubą Roztocką w Tatrzańskim Parku Narodowym. Chrońmy Przyrodę Ojczystą 25: 5-12.

Bel M (1736) Notitia Hungariae novae historico-geographica. Vol. II. Viennae, Austria.

Blada I (2008) Pinus cembra distribution in the Romanian Carpathians. Annals of Forest Research 51: 115-132.

Browicz K \& Gostyńska-Jakuszewska M (1974) Atlas rozmieszczenia drzew i krzewów w Polsce. 15. PWN, Warszawa-Poznań, Poland.

Bukovčan V (1969) Pestovanie limby. Príroda, Bratislava, Czechoslovakia.

Casalegno A, Amatulli G, Camia A, Nelson A \& Pekkarinen A (2010) Vulnerability of Pinus cembra L. in the Alps and the Carpathian mountains under present and future climates. Forest Ecology and Management 259: 750-761. doi:10.1016/j. foreco.2009.10.001.

Caudullo G \& de Rigo D (2016) Pinus cembra in Europe: distribution, habitat, usage and threats: European atlas of forest tree species (ed. by J SanMiguel-Ayanz, D de Rigo, G Caudullo, T Houston Durrant \& A Mauri) Publication Office of the
European Union, Luxembourg City, Luxembourg, pp. 120-121.

Chmiel J (1996) Naturalny zasięg, a rozsiedlenie limby Pinus cembra L. w Tatrach Polskich: Przyroda Tatrzańskiego Parku Narodowego a człowiek. Vol. II. Biologia (ed. by A Kownacki) Komitet Badań Naukowych Tatrzańskiego Parku Narodowego i Polskiego Towarzystwa Przyjaciół Nauk o Ziemi, Oddział Kraków, Kraków, Zakopane, Poland, pp. 63-66.

Cox DR (1958) The regression analysis of binary sequences. Journal of the Royal Statistical Society. Series B Statistical Methodology 20: 215-242.

Dąbrowska K \& Guzik M (2015) Atlas of the Tatra Mountains - Abiotic nature. Tatrzański Park Narodowy, Zakopane, Poland.

Dražil T (2002) Ls9.4 Smrekovcovo-limbové lesy: Katalóg biotopov Slovenska (ed. by V Stanova \& M Valachovič) DAPHNE - Inštitút aplikovanej ekológie, Bratislava, Slovakia.

Dzialuk A, Chybicki I, Gout R, Mączka T, Fleischer P, Konrad H, Curtu AL, Sofletea N \& Valadon A (2014) No reduction in genetic diversity of Swiss stone pine (Pinus cembra L.) in Tatra Mountains despite high fragmentation and small population size. Conservation Genetics 15: 1433-1445. doi:10.1007/s10592-014-0628-6.

Ellenberg H (1978) Vegetation Mitteleuropas mit den Alpen in ökologischer Sicht. 2nd ed. Ulmer Verlag, Stuttgart, Germany.

Erschbamer B \& Wallnöfer S (2007) Vegetation at the upper timberline: Trees at their upper limit (ed. by G Wieser \& M Tausz) Springer, Amsterdam, Netherlands, pp. 67-78.

ESRI (2009) Podręcznik użytkownika ArcGIS Desktop: ArcView, ArcEditor, ArcInfo. ESRI Polska, Poland.

European Environment Agency (2017) Natura 2000 - Standard data form for site: PLC120001 Tatry. http://natura2000.eea.europa.eu/Natura2000/ SDF.aspx? site $=$ PLC120001.

Faliński JB (1990) Kartografia geobotaniczna. Kartografia fitosocjologiczna. Vol. II. Państwowe Przedsiębiorstwo Wydawnictw Kartograficznych im. Eugeniusza Romera, Warszawa, Wrocław, Poland.

Fleischer P \& Chmiel J (2010) Lesy: Tatry - príroda (ed. by A Koutna \& B Chovancova) Baset, Praha, Czech Republic, pp. 279-298.

Holtmeier FK (2003) Mountain timberlines. Ecology, patchiness and dynamics. Kluwer Academic Publishers, Dordrecht, The Netherlands.

Górski P \& Váňa J (2014) A synopsis of liverworts occurring in the Tatra Mountains (Western Carpathians, Poland and Slovakia): checklist, distribution and new data. Preslia 86: 381-485. 
Grodzki W, Zięba A \& Zwijacz-Kozica T (2019 - accepted) Zamieranie limby w Tatrach - ocena skali zjawiska i roli owadów kambiofagicznych. Sylwan.

Holeksa J \& Szwagrzyk J (2004) Górskie bory świerkowe z limbą i modrzewiem: Poradnik ochrony siedlisk i gatunków Natura 2000 Lasy i bory (ed. by J Herbich) Ministerstwo Środowiska, Warszawa, Poland, pp. 312-316.

Jamnický J (1963) Západná hranica prirodzeného rozšírenia borovice limby (Pinus cembra L.) v Karpatoch. Biológia 18: 626-630.

Jamnický J (1964) Prečo a ako sa rúbali limby v Tatrách. Krásy Slovenska 41: 390-392.

Jamnický J (1981) Rozšírenie a stav borovice limby (Pinus cembra L.) v Západných Karpatoch. Zborník prác o Tatranskom Národnom Parku 22: 5-29.

Jasičová M (1966) Coniferophytina: Flóra Slovenska II (ed. by J Futák) Vydavtelstvo Slovenskej akademie vied, Bratislava, Czechoslovakia, pp. 280-284.

Kanka R (2008) Lesy Belianských Tatier. Veda, Bratislava, Slovakia.

Kučera P (2017) Two groups of Pinus cembra forest communities in the Tatras. Acta Botanica Hungarica 59: 389-425. doi:10.1556/034.59.2017.3-4.7.

Kučera P (2018) Erratum. Acta Botanica Hungarica 60: 235-236. doi:10.1556/034.60.2018.1-2.12.

Leuschner C \& Ellenberg H (2017) Ecology of Central European forests: vegetation ecology of Central Europe. Vol. I. Springer International Publishing, Cham, Switzerland.

Madeyski S (1974) Modrzew Larix decidua Mill. Studia ośrodka dokumentacji fizjograficznej 3: 71-85.

Matuszkiewicz W (2008) Przewodnik do oznaczania zbiorowisk roślinnych Polski. Vademecum Geobotanicum 3. Wydawnictwo Naukowe PWN, Warszawa, Poland.

Mirek Z (1996) Tatry i Tatrzański Park Narodowy wiadomości ogólne: Przyroda Tatrzańskiego Parku Narodowego (ed. by Z Mirek) Tatrzański Park Narodowy, Kraków, Zakopane, Poland, pp. 17-26.

Mirek Z, Michalik S, Holeksa J, Czerny M, Krawiec A, Mroczek K, Szmalec T, Łaptosz J, Myjak P, Mitka K, Bodzioch R \& Lomber J (2013) Operat ochrony ekosystemów leśnych i zaroślowych. Kraków, Poland. (unpublished)

Mirek Z \& Piękoś-Mirkowa H (2003) Kwiaty Tatr. Multico Oficyna Wydawnicza, Warszawa, Poland.

Mráz P \& Ronikier M (2016) Biogeography of the Carpathians: evolutionary and spatial facets of biodiversity. Biological Journal of the Linnean Society 119: 528-559. doi:10.1111/bij.12918.

Myczkowski S (1969) Limba Pinus cembra L. wysokogórskie drzewo lasu tatrzańskiego. Sbornik prác o Tatranskom Narodnom Parku 11: 99-138.

Myczkowski S (1971) Rozmieszczenie: Limba Pinus cembra L. Nasze drzewa Leśne. Vol. II. (ed. by S
Białobok) PWN, Warszawa, Poznań, Poland, pp. 23-49.

Myczkowski S \& Bednarz Z (1974) Limba Pinus cembra L.: Studia ośrodka dokumentacji fizjograficznej 3: 111-139.

Myczkowski S, Bednarz Z \& Lesiński J (1971) Zarys ekologii: Limba Pinus cembra L. Nasze drzewa Leśne. Vol. II. (ed. by S Białobok) PWN, Warszawa, Poznań, Poland, pp. 77-98.

Myczkowski S \& Lesiński J (1974) Rozsiedlenie rodzimych gatunków drzew tatrzańskich. Studia ośrodka dokumentacji fizjograficznej 3: 13-70.

Nazimova DI \& Polikarpov NP (1996) Forest zones of Siberia as determined by climatic zones and their possible transformation trends under global change. Silva Fennica 30: 201-208.

Ochyra R (1996) Mchy: Przyroda Tatrzańskiego Parku Narodowego (ed. by Z Mirek) Tatrzański Park Narodowy, Kraków, Zakopane, Poland, pp. 319334.

Ozenda P (1983) La végétation de l'arc alpin. Council of Europe, Strasbourg, France.

Paryski WH (1971) Użytkowanie limby: Limba Pinus cembra L. Nasze drzewa Leśne. Vol. II. (ed. by S Białobok) PWN, Warszawa, Poznań, Poland, pp. 108-115.

Pawłowski B (1956) Flora Tatr: rośliny naczyniowe. PWN, Warszawa, Poland.

Piękoś-Mirkowa H \& Mirek Z (1996) Zbiorowiska roślinne: Przyroda Tatrzańskiego Parku Narodowego (ed. by Z Mirek) Tatrzański Park Narodowy, Kraków, Zakopane, Poland, pp. 237-274.

Piotrowska K, Danel W, Iwanow A, Gaździcka E, Rączkowski W, Bezák V, Maglay J, Polák M, Kohút M \& Gross P (2015) Geology: Atlas of the Tatra Mountains - Abiotic nature (ed. by K Dąbrowska \& M Guzik) Tatrzański Park Narodowy, Zakopane, Poland.

Pohar M, Blas M \& Turk S (2004) Comparison of logistic regression and linear discriminant analysis: a simulation study. Metodoloski Zvezki 1: 143-161.

R Development Core Team (2018) R: A language and environment for statistical computing. R Foundation for Statistical Computing, Vienna. http:// www.Rproject.org.

Rencher AC \& Schaalje GB (2008) Linear models in statistics. 2nd ed. John Wiley \& Sons Inc., Hoboken, New Jersey, USA.

Skiba S, Koreň M, Drewnik M \& Kukla J (2015) Soils: Atlas of the Tatra Mountains - Abiotic nature (ed. by K Dąbrowska \& M Guzik) Tatrzański Park Narodowy, Zakopane, Poland.

Skrzydłowski T, Wróbel S \& Mączka T (2011) Kosmatki, szczawióry i dzwonki. Tatry TPN 38: 4649. 
Sokołowski M (1928) O górnej granicy lasu w Tatrach. Wydawnictwo Fundacji „Zakłady Kórnickie", Kraków, Poland.

Somora J (1958) O rozšírení niektorých lesných drevín v skupine Lomnického štítu. Vyd. Osveta, Martin, Czechoslovakia.

Somora J (1959) O rozšírení borovice limby (Pinus cembra L.) a tisu obyčajného (Taxus baccata L.) V Belanských Tatrách. Sbornik prác o Tatranskom Narodnom Parku 3: 85-126.

Szumilas M (2010) Explaining odds ratios. Journal of the Canadian Academy of Child and Adolescent Psychiatry 19: 227-229.

Szweykowski (1996) Wątrobowce: Przyroda Tatrzańskiego Parku Narodowego (ed. by Z Mirek) Tatrzański Park Narodowy, Kraków, Zakopane, Poland, pp. 335-346.

Środoń A (1936) Rozmieszczenie limby w polskich Karpatach i jej ochrona. Ochrona Przyrody 16: 22-42.

Tobolewski (1996) Porosty: Przyroda Tatrzańskiego Parku Narodowego (ed. by Z Mirek) Tatrzański Park Narodowy, Kraków, Zakopane, Poland, pp. 363-378.

Tranquillini W (1979) Physiological ecology of the alpine timberline: tree existence at high altitudes with special reference to the European Alps. Springer, Berlin, Germany.

Ustrnul Z, Walawender E, Czekierda D, Štastný P, Lapin M \& Mikulová K (2015) Precipitation and snow cover: Atlas of the Tatra Mountains - Abiotic Nature (ed. by K Dąbrowska \& M Guzik) Tatrzański Park Narodowy, Zakopane, Poland.

Valachovič M (2014) Limbové lesy v Mengušovskej doline (Vysoké Tatry). Naturae Tutela 18: 21-28.

Willner W \& Grabherr G (2007) Die Wälder und Gebüsche Österreichs. Elsevier GmbH, Spektrum Akademischer Verlag, München, Germany.
Wojkowski J (2015) Solar radiation: Atlas of the Tatra Mountains - Abiotic Nature (ed. by K Dąbrowska \& M Guzik) Tatrzański Park Narodowy, Zakopane, Poland.

Wojterska M, Wojterski T, Szwed W \& Piaszyk M (2004) Spruce forests in the Roztoka Valley in the High Tatras: Coniferous forest vegetation: differentiation, dynamics and transformations (ed. by A Brzeg \& M Wojterska) Wydawnictwo Naukowe UAM, Seria Biologia 69, Poznań, Poland, pp. 115128.

Zarzycki K, Trzcińska-Tacik H, Różański W, Szeląg Z, Wolek J \& Korzeniak U (2002) Ecological Indicator Values of vascular plants of Poland: Biodiversity of Poland. Vol. 2. (ed. by Z Mirek) W. Szafer Institute of Botany, Polish Academy of Sciences, Kraków, Poland.

Zielonka T (2010) Las urwiskowy - życie na krawędzi. Tatry 33: 52-55.

Zięba A, Różański W \& Szwagrzyk J (2018) Syntaxonomy of relic Swiss stone pine (Pinus cembra) forests in the Tatra Mountains. Tuexenia 38: 155176. doi:10.14471/2018.38.004.

Zwijacz-Kozica T \& Żywiec M (2007) Fifty-year changes in a strictly protected stone pine population in the Tatra National Park. Nature Conservation 64: 73-82.

Zwijacz-Kozica T, Żywiec M \& Zwijacz-Kozica M (2010) Występowanie limby i modrzewia europejskiego w Dolinie Suchej Wody na tle warunków środowiska: Przyroda Tatrzańskiego Parku Narodowego a Człowiek. Vol. II. Nauki biologiczne (ed. by Z Mirek) Wydawnictwa Tatrzańskiego Parku Narodowego, Zakopane, Poland, pp. 25-30.

Żmudzka E, Nejedlík P \& Mikulová K (2015) Temperature, thermal indices: Atlas of the Tatra Mountains - Abiotic Nature (ed. by K Dąbrowska \& M Guzik) Tatrzański Park Narodowy, Zakopane, Poland. 